\title{
Growth of the peritrich epibiont Zoothamnium intermedium Precht, 1935 (Ciliophora, Peritrichia) estimated from laboratory experiments
}

\author{
$U t z, L R P$ * \\ Departamento de Zoologia, Universidade Federal do Rio Grande do Sul - UFRGS, \\ Av. Bento Gonçalves, 9500, CEP 91501-970, Porto Alegre, RS, Brazil \\ *e-mail: laurautz@yahoo.com \\ Received November 28, 2006 - Accepted February 12, 2007 - Distributed May 31, 2008 \\ (With 2 figures)
}

\begin{abstract}
Peritrich ciliates are commonly found colonizing living substrates. Although this a well known phenomenon, biological aspects of this relationship need to be studied in more detail. Assessment of growth rates in peritrichs has been the subject of very few studies. Only species in the genera Carchesium Ehrenberg, 1830 and Vorticella Linnaeus, 1767 had their growth rates evaluated in the field and in the laboratory. In the present study, growth, colonization (colonies/host), and proliferation (zooids/colony) rates of the peritrich epibiont Zoothamnium intermedium Precht, 1935 attached to the calanoid copepod Acartia tonsa Dana 1848 were evaluated in the laboratory in two food regimes: bacteria only, and algal based diet. Results showed that growth, colonization, and proliferation rates were similar for both diets. Maximum growth rates obtained for Z. intermedium was 0.85 and 0.83 per day, for bacteria and algae respectively. Maximum colonization rates were 0.5 per day for both diets, and the maximum proliferation rates were 0.44 and 0.42 per day for bacteria and algae respectively. These results demonstrate that Z. intermedium is able to grow at the same rate of other peritrichs on bacterial and algal based diets.
\end{abstract}

Keywords: ciliates, comensalism, Acartia tonsa, copepods, bacteria.

\section{Crescimento do peritríquio epibionte Zoothamnium intermedium Precht, 1935 (Ciliophora, Peritrichia) obtido através de experimentos em laboratório}

\begin{abstract}
Resumo
Ciliados peritríquios são geralmente encontrados colonizando a superfície de outros organismos. Embora este fenômeno seja bem documentado, certos aspectos biológicos desta associação ainda precisam ser estudados. Taxas de crescimento em peritríquios foram objeto de pouquíssimos estudos, visto que apenas espécies nos gêneros Carchesium e Vorticella tiveram suas taxas de crescimento calculadas em experimentos de campo e de laboratório. No presente trabalho, taxas de crescimento, colonização (colônias/hospedeiro) e proliferação (zooides/colônia) do peritríquio epibionte Zoothamnium intermedium colonizando o copépodo calanoide Acartia tonsa foram avaliadas em laboratório com duas dietas: bactéria somente e alga. Resultados demonstraram que taxas de crescimento, colonização e proliferação foram semelhantes para as duas dietas. A taxa de crescimento máxima observada para Z. intermedium foi de 0.85 e 0.83 por dia para bactéria e alga, respectivamente. A taxa máxima de colonização foi 0.5 por dia para as duas dietas e a taxa máxima de proliferação foi de 0.44 e 0.42 por dia para bactéria e alga, respectivamente. Estes resultados demonstram que $Z$. intermedium cresce em taxas semelhantes a outras espécies de peritríquios em dietas de bactérias ou de algas.
\end{abstract}

Palavras-chave: ciliados, comensalismo, Acartia tonsa, copépodos, bactéria.

\section{Introduction}

Peritrich ciliates commonly colonize planktonic crustacea (Hermann and Mihursky, 1964; Green, 1974; Henebry and Ridgeway, 1979; López et al., 1998), with the majority of the reports on this epibiotic relationship focusing on the effects of these epibionts on host survivorship and reproduction (Kankaala and Eloranta, 1987;
Xu and Burns, 1991; Xu, 1992; Weissman et al., 1993). However, studies emphasizing aspects of the peritrich life cycle such as growth rates of these ciliates are still lacking.

Assessment of community composition and growth rates of free-living peritrichs have been the subject of 
only a few studies in freshwater environments, such as streams and activated sludge plants (Curds and Vandyke, 1966; Taylor, 1983; Kusuoka and Watanabe, 1987; Harmsworth et al., 1992; Harmsworth and Sleigh, 1993). In these researches it was demonstrated that peritrichs have an important role in controlling bacterial populations, especially in waster water treatment systems. One of the most comprehensive studies of in situ growth of the peritrichs in the field was performed by Kusuoka and Watanabe (1987) in an urban stream in Japan. They sampled colonies of Carchesium polypinum Linnaeus, 1758 and individuals of Vorticella microstoma Ehrenberg, 1830 attached to transparent plastic films and found growth rates of 1.37 and 1.01 per day for the two peritrichs respectively. Considering peritrichs as epibionts, only one study so far, performed by Gilbert and Schröder (2003) has dealt with growth rates of peritrichs attached to living substrates in the laboratory. The authors observed an exponential growth of colonies of Epistylis pygmaeum Ehrenberg, 1838, from a single zooid, attached to the rotifer Brachionus angularis (Gosse, 1851), but no actual growth or colonization rates were calculated for the trophont stage of this species.

In the present study, growth, colonization, and proliferation rates of the peritrich epibiont Zoothamnium intermedium were evaluated in the laboratory, feeding on bacteria alone and on a mixture of bacteria and Isochrysis galbana Stein, 1878. This diet was chosen because peritrichs are primarily bacterivores (Corliss, 1979) and it was observed from laboratory cultures that these ciliates are able to feed on I. galbana. This is the first study to investigate growth rates of a peritrich epibiont species attached to a crustacean host.

\section{Materials and Methods}

\subsection{Cultures of Acartia tonsa, Eurytemora affinis (Poppe, 1880) and their epibionts}

A. tonsa and E. affinis were collected with a plankton net ( $202 \mu \mathrm{m}$ mesh size) from the Patuxent River (a tributary of the Chesapeake Bay) brought alive to the laboratory and examined for the presence of ciliate epibionts. Copepods were transferred to 4 - L beakers ( 3 cultures for each species) containing $2 \mathrm{~L}$ of $<0.45 \mu \mathrm{m}$ filtered seawater with salinity adjusted for 15 psu. Cultures of clean copepods (without epibionts) and of copepods carrying $Z$. intermedium were maintained following the methods described in Utz and Coats (2005). The cultures were maintained in the laboratory for at least two weeks before starting the experiments. Copepods were used in the experiments as substrate for $Z$. intermedium, since this peritrich does not attach to non-living substrates.

\subsection{Growth rates of Z. intermedium feeding on bacteria}

To assess growth rates of $Z$. intermedium feeding on bacteria alone, the development of colonies was observed over a period of 96 hours. The production of telotrochs was induced by killing A. tonsa colonized by Z intermedium.
After about 2 hours following the death of the hosts, the peritrich started to form free-swimming stages that were harvested and exposed to live, clean A. tonsa. Hosts carrying a single zooid were transferred to glass Petri dishes (147 $\mathrm{mm}$ in diameter) filled with $150 \mathrm{~mL}$ of $<0.45 \mu \mathrm{m}$ 15 psu water, enriched with varying amounts of Cerophyl ${ }^{\circledR}$ to reach different bacterial concentrations. These Petri dishes were incubated for 3 days before the beginning of the experiment to allow bacterial growth. As food for the copepods, the diatom Thalassiosira weisflogii (Grunow, 1880), cultured as described in Utz and Coats (2005), was added at a final concentration of $1 \times 103$ cells. $\mathrm{mL}^{-1}$. The experiment had a total of five treatments (bacterial concentrations of $10^{4}, 10^{5}, 10^{6}, 10^{7}$, and $10^{8}$ ) with three replicates per treatment and one infested host per replicate. Experimental chambers were kept in an incubator at $20^{\circ} \mathrm{C}$ with photoperiod of 14:10 light:dark hours. Copepods were observed in dissecting microscope (40x magnification) every 24 hours for a period of four days for the total number of attached zooids; the number of colonies per host and mean number of zooids per colony were recorded. Growth rates (rate of change in number of epibiont zooids) were calculated using the following formula: $\ln \left(\mathrm{N}_{\mathrm{t}}\right)=\ln \left(\mathrm{N}_{0}\right)+\mathrm{rt}$, where, $\mathrm{N}_{\mathrm{t}}$ is the number of zooids at time $\mathrm{t} ; \mathrm{N}_{0}$ is the number of zooids at time 0 ; $\mathrm{t}$ is the period of time in days; and $\mathrm{r}$ is the growth rate. Colonization rates (rate of change in number of epibiont colony) were calculated using the same formulae as suggested by Kusuoka and Watanabe (1987): $\ln \left(\mathrm{N}_{\mathrm{t}}{ }^{\prime}\right)=\ln \left(\mathrm{N}_{0}{ }^{\prime}\right)+\mathrm{r}^{\prime} \mathrm{t}$, where, $\mathrm{N}_{\mathrm{t}}{ }^{\prime}$ is the number of epibiont colonies at time $t ; \mathrm{N}_{0}$ ' is the number of the epibiont colonies at time 0 , $t$ is the period of time in days; and r' is the colonization rate. Proliferation rates (rate of change in the mean number of epibiont zooids/colony) were calculated using the same formulae: $\ln \left(\mathrm{N}_{\mathrm{t}}\right.$ ") $=\ln \left(\mathrm{N}_{0}\right.$ ") $+\mathrm{r}$ " $\mathrm{t}$; where $\mathrm{N}_{\mathrm{t}}$ " is the mean number of epibiont zooids/colony at time $\mathrm{t} ; \mathrm{N}_{0}$ ", is the mean number of epibiont zooids/colony at time 0 ; $t$ is the time in days; and r" is the proliferation rate.

A water sample $(5 \mathrm{~mL})$ from each replicate was taken at the beginning $\left(\mathrm{T}_{0}\right)$ and at the end of the experiment $\left(\mathrm{T}_{4}\right)$, and preserved with formaldehyde for the enumeration of bacteria using the DAPI staining technique (Porter and Feig, 1980). Counts were performed using an Axioscope equipped with optics epifluorescence (Zeiss Corp.). For each replicate, duplicate counts were carried out up to a total of 200 cells/count. The enumeration of background bacteria was performed by replicate counts of blank filters (for each concentration) and the result was included in the calculation of bacterial concentration.

\subsection{Growth rates of $Z$. intermedium feeding on Isochrysis galbana based diet}

To determine growth rates of $Z$. intermedium feeding primarily on the haptophyte algae Isochrysis galbana, the development of colonies originated from a single zooid was observed over a period of 96 hours. The experimental set up used in this experiment was the same used to assess the growth rates of the epibiont feeding on bacteria. The experiment had a total of six concentrations of I. galbana $\left(10^{1}, 10^{2}, 10^{3}, 10^{4}, 105\right.$, and $10^{6}$ cells. $\left.\mathrm{mL}^{-1}\right)$ with three repli- 
cates per treatment and one infested $A$. tonsa per replicate. The number of zooids and colonies per host and the mean number of zooids per colony were recorded every 24 hours for 96 hours. A water sample $(5 \mathrm{~mL})$ from each replicate was taken at every observation point and fixed with acid Lugol's for enumeration of I. galbana. Concentration of algal food was assessed by direct counts using a PalmerMaloney counting chamber. Triplicate counts were performed for each replicate to a total of 100 cells/count.

\section{Results}

The growth rates of $Z$. intermedium (number of zooids/host/unit of time), feeding on bacteria alone and algae are presented in Figures 1a and b. The presence of green food vacuoles inside the cells demonstrated that Z. intermedium was able to feed and that algae was a significant portion of its diet. In both diets a similar pattern was observed where growth rates increased with increasing food concentration until a threshold was reached. Additional increases in food concentration either resulted in no change in growth (Figure 1a) or in a decrease in growth rate (Figure 1b). In the experiment with bacteria as the main food, the maximum growth rate $(\mu)$ estimated from the mean growth rates of three replicates was 0.8 per day $(\mathrm{SE}=0.007)$ and was reached at a concentration of $10^{6}$ cells. $\mathrm{mL}^{-1}$. In the experiment with algae as the main food, the maximum growth rate, estimated as in the bacteria experiment, was 0.83 per day $(\mathrm{SE}=0.03)$ and was reached at a concentration of $10^{5}$ cells. $\mathrm{mL}^{-1}$. The maximum doubling rate of $Z$. intermedium was 1.20 and 1.23 per day in the experiments with algae and bacteria respectively.

Figures $1 \mathrm{c}$ and $\mathrm{d}$ show the colonization rates (increase of colonies/host) of Z. intermedium on A. tonsa feeding on bacteria and algae respectively. With both diets, colonization rates increased with an increasing food concentration until a maximum was reached. Further increases in food concentration, in both cases, resulted in a decrease in the colonization rates after reaching this maximum (Figures 1c and d). In the experiment with bacteria, the maximum colonization rate was 0.50 per day $(\mathrm{SE}=0.04)$ and was observed at a concentration of $10^{7}$ cell. $\mathrm{mL}^{-1}$, one order of magnitude higher than the observed growth rates. Colonization rates in an algal-based diet were similar to those observed for bacteria alone. The maximum rate was 0.51 per day $(\mathrm{SE}=0.01)$ and was observed at the same concentration for which maximum growth rates were achieved $\left(10^{5}\right.$ cells. $\left.\mathrm{mL}^{-1}\right)$.

The mean number of zooids per colony (proliferation rate) of $Z$. intermedium was also similar for bacterial and algal diets (Figures 1e and f). With a diet based on bacteria, the maximum proliferation rate was 0.44 per day $(\mathrm{SE}=0.04)$ and was reached at a concentration of $10^{6}$ cells. $\mathrm{mL}^{-1}$ (Figure 1e). Differently from the bacterial diet and from the growth and colonization rates, the proliferation rate on an algal diet did not reach a plateau, and the highest rate of $0.42(\mathrm{SE}=0.038)$ was recorded at $10^{6}$ cells. $\mathrm{mL}^{-1}$ (Figure 1f). Algae concentration remained fairly constant throughout the study, as can be seen in Figures $2 \mathrm{a}$ and $\mathrm{b}$.

\section{Discussion}

Studies focusing on the growth rates of peritrichs in the laboratory or in the field are scarce (Curds and Vandyke, 1966; Sudo and Aiba, 1971; Kusuoka and Watanabe,1987) however, these ciliates are important consumers of bacteria in aquatic environments, especially eutrophic habitats, due to their high metabolic rates (Fenchel, 1987). Z. intermedium, in the present study, had a maximum population growth rate of approximately 0.8 per day (Figures $1 \mathrm{a}$ and $\mathrm{b}$ ) when exposed to diets based primarily on bacteria or Isochrysis galbana, demonstrating that this peritrich is able to grow at approximately the same rate when the main available food is bacteria or small algae. No other study assessing growth rates of a species in the genus Zoothamnium is yet available, but, when compared to another peritrich, the growth rates of $Z$. intermedium are lower than those found for Carchesium polypinum in the field (1.4 per day; Kusuoka and Watanabe, 1987), or in the laboratory (1.8 per day; Sudo and Aiba, 1971). On the other hand, the growth rates found for $Z$. intermedium were similar to those reported for other species of ciliates. For example, Jack and Gilbert (1993) found maximum growth rates of 0.87 per day for the oligotrich ciliate Strobilidium gyrans (Stokes, 1887), and 0.86 per day for Euplotes eurystomus (Wrzesniowski, 1870) feeding on a cryptomonad algae at a temperature of $20^{\circ} \mathrm{C}$.

The only other record of growth rates estimated in the laboratory for a peritrich epibiont is that of Gilbert and Schröder (2003), who observed colony development of Epistylis pygmaeum attached to Brachionus angularis. They reported an exponential increase in zooids and the colonies originated from a single attached zooid, but the actual growth rates were not calculated for the trophont stage.

The maximum rate at which $Z$. intermedium on A. tonsa formed new colonies (colonization rates) was approximately 0.4 per day at a concentration of $10^{7}$ bacteria cells. $\mathrm{mL}^{-1}$ or $10^{6}$ algal cells. $\mathrm{mL}^{-1}$ (Figures 1c and d), and was much lower than the actual growth rate (zooids/host) for this species. Interestingly, Kusuoka and Watanabe (1987) found colonization rates of $C$. polypinum higher than the actual growth rate estimated for the same species, due to the migration of telotrochs from other sites, since their experiment was performed in situ. By contrast, in the present study no other population of $Z$. intermedium was present and new colonies were formed from telotrochs originated by binary fission from the original zooid, or in later stages by direct transformation of the trophont stage.

Proliferation rates (i.e. number of zooids/colony) of $Z$. intermedium reached a plateau when these peritrichs had bacteria as the main food (Figure 1e). On the other hand, in the algal-based diet the number of zooids per colony continued to increase with higher 

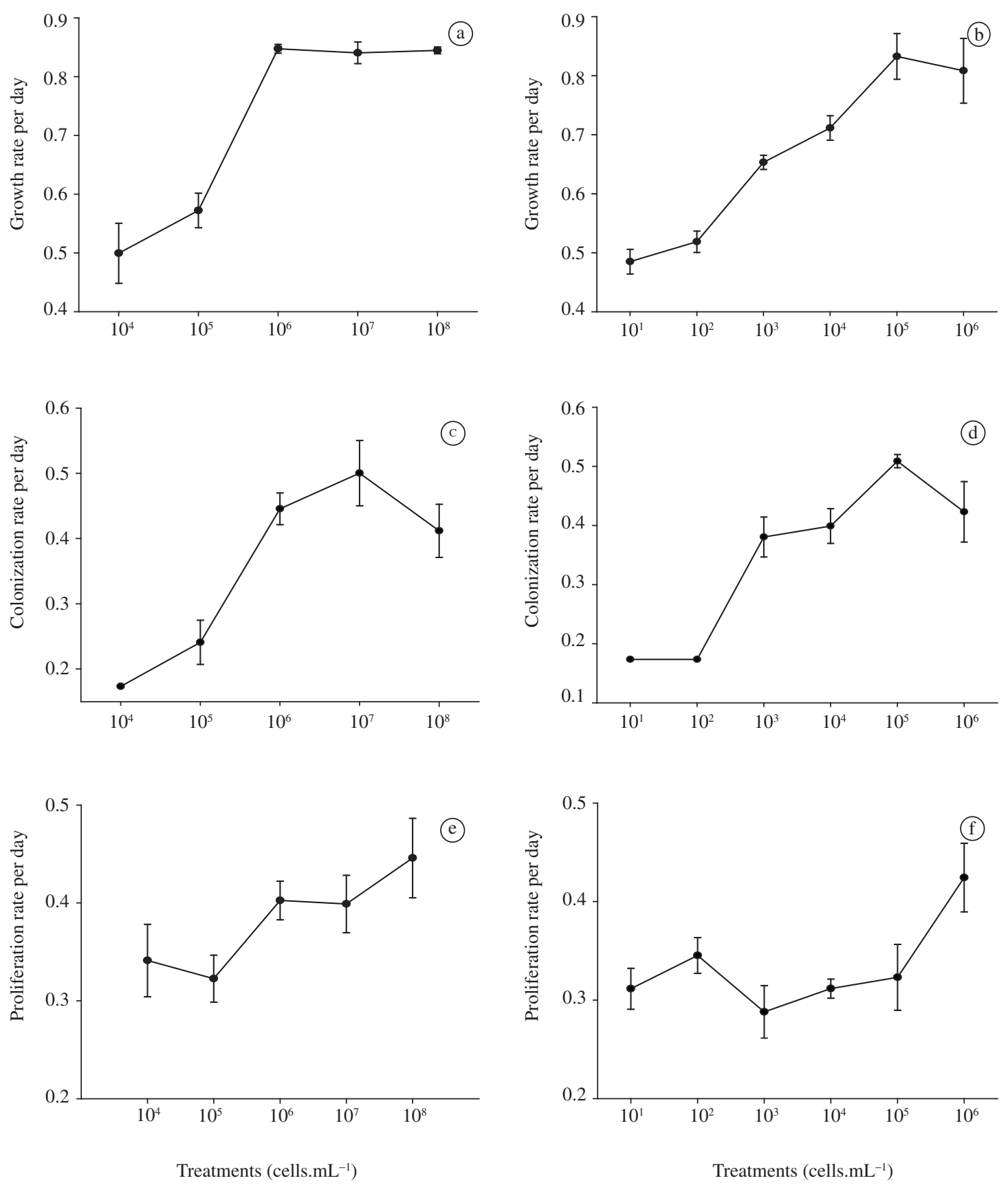

Figure 1. Growth, colonization and proliferation rates of Zoothamnium intermedium attached to Acartia tonsa. Figures 1a, c and e show results obtained with a diet based primarily on bacteria, and Figures $1 \mathrm{~b}, \mathrm{~d}$ and $\mathrm{f}$ represent a diet based primarily on Isochrysis galbana. Symbols are the means of three replicates and error bars are the Standard Error of the Mean.

food concentration (Figure 1f). This observation is in agreement with the fact that abundance of certain species of epibionts varies with the degree of eutrophication of aquatic environments (Henebry and Ridgeway, 1979; Mannesmann and Rustige, 1994). Mannesmann and Rustige (1994) found a strong correlation between the increase in epibiont abundance on the amphipod
Gammarus pulex Linnaeus, 1758 and the increase in organic load. Although they only tested polluted environments, the correlation between load and eutrophication observed by them in the field and suggested by laboratory experiments in the present study, could provide some insights about the relationship between epibiont load and organic pollution. 

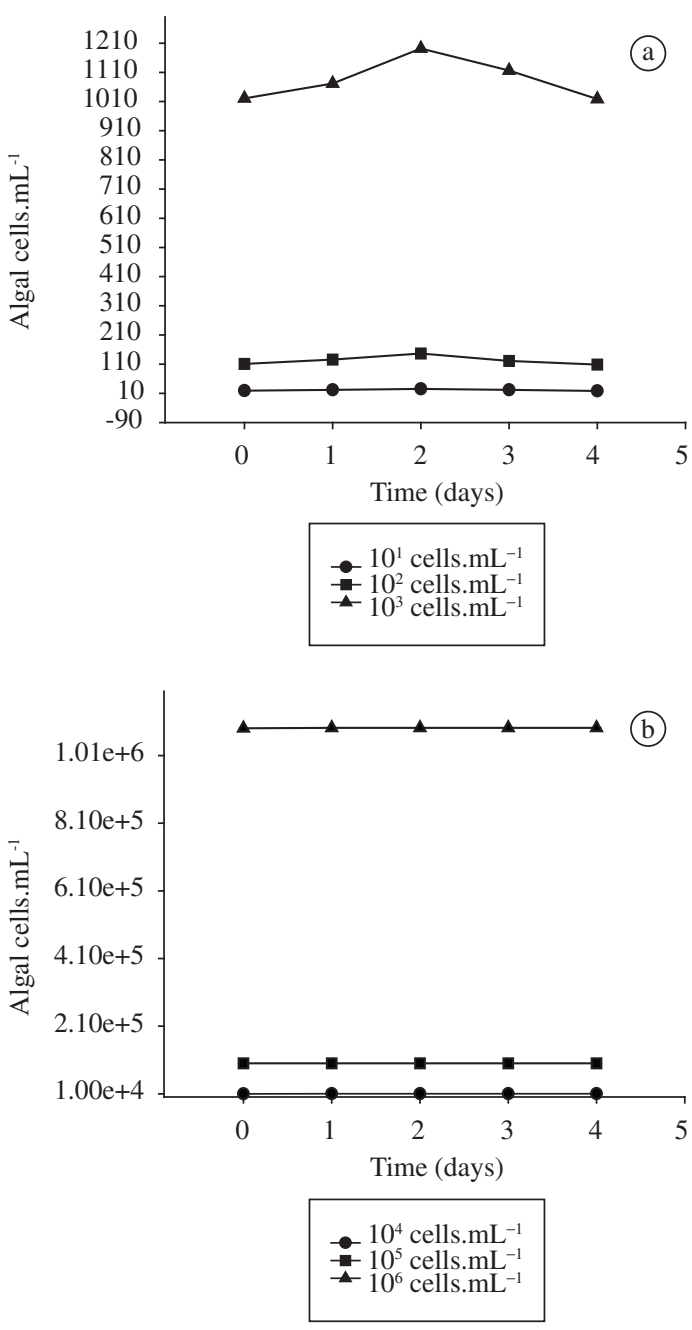

\section{References}

CORLISS, JO., 1979. The ciliated Protozoa. . New York: Pergamon Press. 455 p.

CURDS, CR. and VANDYKE, JM., 1966. The feeding habits and growth rates of some fresh-water ciliates found in activatedsludge plants. J. Appl. Ecol., vol. 3, no. 1, p. 127-137.

FENCHEL, T., 1987. Ecology of Protozoa: The biology of free-living phagotrophic protists. Wisconsin: Science Tech. Publishers. $192 \mathrm{p}$.

GILBERT, JJ. and SCHRÖDER, T., 2003. The ciliate epibiont Epistylis pygmaeum: selection for zooplankton hosts, reproduction and effect on two rotifers. Fresh. Biol, vol. 48, no. 5 , p. $878-893$.

GREEN, J., 1974. Parasites and epibionts of cladocera. Trans. Zool. Soc. London, vol. 32, p. 417-515.

HARMSWORTH, GC., SLEIGH, MA. and BAKER, JH., 1992. The abundance of different peritrich ciliates on stone surfaces in contrasting lowland streams throughout the year. J. Protozool., vol. 39, no.1, p. 58-65.

HARMSWORTH, GC. and SLEIGH, MA., 1993. Colonization of non-living surfaces in streams by peritrich ciliates. Eur. J. Protist., vol. 29, no. 3, p. 294-301.

HENEBRY, MS. and RIDGEWAY, BT., 1979. Epizoic ciliated protozoa of planktonic copepods and cladocerans and their possible use as indicators of organic pollution. Trans. Am. Micros. Soc., vol. 98, no. 4, p. 495-508.

HERMAN, SS. and MIHURSKY, JA., 1964. Infestation of the copepod Acartia tonsa with the stalked ciliate Zoothamnium. Science, vol. 146, p. 543-544.

JACK, JD. and GILBERT, JJ., 1993. Effects of metazoan predators on ciliates in freshwater plankton communities. J. Euk. Microbiol., vol. 44, no. 3, p. 194-199.

KANKAALA, P. and ELORANTA, P., 1987. Epizooic ciliates (Vorticella sp.) compete for food with their host Daphnia longispina in a small polyhumic lake. Oecologia, vol. 73, no.2, p. 203-206.

Figure 2. Concentration of Isochrysis galbana observe throughout the growth rate experiment. Figure $2 \mathrm{a}$ shows fluctuation of I. galbana at concentrations of $10^{1}, 10^{2}$, and $10^{3}$ cells. $\mathrm{mL}^{-1}$, and Figure 2b shows concentrations of $10^{4}$, $10^{5}$, and $10^{6}$.

In summary, this study analyzed the growth rates of a peritrich epibiont feeding on bacteria and small algae demonstrating that $Z$. intermsedium is able to grow on an exclusively bacterial diet as well as on an algal based diet. The methods described here also could be used as models to study growth rates of other species of peritrichs, whether epibionts or not.

Acknowledgements - I would like to thank Dr. D. Wayne Coats for his intellectual and logistic help. I also would like to thank Drs. Eugene Small, Diane Stoecker, Michael Roman, Marie Bundy, Darcy Lonsdale, Stephen Wolniak, Eduardo Eizirik, and the two anonymous reviewers for their help and constructive suggestions. I was supported by a Pre-Doctoral fellowship from Capes, Brazil. This work was developed at the Smithsonian Environmental Research Center, while I was a Ph.D. student at the University of Maryland at College Park.

KUSUOKA, Y. and WATANABE, Y., 1987. Growth and survival of peritrichs ciliates in an urban stream. Oecologia, vol. 73, no. 1 , p. 16-20.

MANNESMANN, R. and RUSTIGE, KH., 1994. Correlation of epizoic ciliates of Gammarus pulex and freshwater quality. Zeit. Ange. Zool., vol. 80, no. 4, p. 486-499.

LÓPEZ, C., OCHOA, E., PÁEZ, R. and THEIS, S., 1998. Epizoans on a tropical freshwater crustacean assemblage. Mar. Fresh. Res., vol. 49, no. 3, p. 271-276.

PORTER, KG. and FEIG, YS., 1980. The use of DAPI for identifying and counting aquatic microflora. Limnol. Oceanogr., vol. 25 , no. 5 , p. $943-948$.

SUDO R. and AIBA, S., 1971. Growth rate of Vorticellidae isolated from activated sludge. Jap. J. Ecol., vol. 21, no. 2, p. 70-76.

TAYLOR, WD., 1983. A comparative study of the sessile, filter-feeding ciliates of several small streams. Hydrobiologia, vol. 98 , no. 2, p. 125-133. 
UTZ, LRP. and COATS, DW., 2005. Spatial and temporal patterns in the occurrence of peritrich ciliates as epibionts on calanoid copepods in the Chesapeake Bay, USA. J. Eukaryot. Microbiol., vol. 52, no. 3, p. 236-244.

WEISSMAN, P., LONSDALE, DJ. and YEN, J., 1993. The effect of peritrich ciliates on the production of Acartia hudsonica in Long Island Sound. Limnol. Oceanogr., vol. 38, no. 3, p. 613-622.
XU, Z., 1992. The abundance of epizoic ciliate Epistylis daphniae related to their host Moina macrocopa in an urban stream. J. Inv. Pathol., vol. 60, no. 2, p. 197-200.

XU, Z. and BURNS, CW., 1991. Effects of the epizoic ciliate Epistylis daphinae, on growth, reproduction and mortality of Boeckella triarticulata (Thompson) (Copepoda:Calanoida). Hydrobiologia, vol. 209, no. 3, p. 183-189. 